\title{
TRANSFORMASI DESAIN TAROMPA DATUAK DALAM KONTEKS PERUBAHAN SOSIOKULTURAL
}

\author{
Amrizal dan Sumadi \\ Dosen Program Studi Seni Kriya FSRD ISI Padangpanjang \\ E-mail: amrimuchtar2i@gmail.com
}

\begin{abstract}
ABSTRAK. Tarompa Datuak adalah alas kaki yang secara sosiokultural merupakan produk budaya yang terinspirasi dari replika "capal Rasul" yang dibawa oleh saudagar dari Arab dan India. Sesuai dengan pepatah Minang "sakali aie gadang sakali tapian barubah" (perubahan waktu) dalam konteks sosialkultural tarompa yang awalnya berbentuk replika capal Rasul bertransformasi di tanah Melayu menjadi "capal Melayu" dan di Ranah Minang disebut dengan“tarompa datuak", karena menjadi bagian dari pakaian kebesaran Datuak. ransformasi desain tarompa datuak menjadi keharusan dalam konteks perubahan sosiokultural, karena menjadi bagian dari pelestarian produk budaya dan pengembangan potensi tarompa datuak yang dilakukan secara optimal dapat memberikan kesejahteraan bagi masyarakat pendukungnya. Untuk itu, perlu dilakukan penelitian ini dengan tujuan untuk mengembangkan desain dan kemampuan perajin tarompa datuak serta memperbaiki sistem manajerial usahanya, sehingga potensi kerajinan tarompa datuak dapat dioptimalkan dan menjadi produk kerajinan tangan yang dapat bersaing ditengah percaturan budaya global. Metode yang digunakan dalam penelitian ini mengacu pada metodologi penelitian kualitatif, yaitu metode observasi partisipatif, yaitu observasi aktif. Untuk membuat desain tarompa datuak, kemudian dilakukan beberapa tahap penelitian, yaitu: survei ke pusat kerajinan tarompa datuak; eksplorasi; analisis dan sintesis; perancangan dengan mempertimbangkan faktor kinerja, faktor fungsi, faktor pemasaran dan minat konsumen; lalu ditransformasikan menjadi prototipe tarompa datuak. Untuk pemberdayaan perajin diadakan pelatihan kewirausahaan yang berbasis teknologi.
\end{abstract}

Kata kunci: Transformasi, Tarompa Datuak, Pengembangan Desain, Sosiokultural, Kewirausahaan.

\section{DESIGN TAROMPA DATUAK TRANSFORMATION IN CONTEXT OF SOCIOCULTURAL CHANGE}

\begin{abstract}
Tarompa Datuak is sociocultural footwear which is a cultural product inspired by a replica "capal Rasul" brought by merchants from Arab and India. In accordance with the Minang proverb "sakali aie gadang sakali tapian barubah" (time change) in the socio-cultural context of tarompa which was originally shaped replica capal Rasul transformed in Malay land into "capal Melays" and in Ranah Minang called "tarompa datuak", as being part of Datuak greatness clothes. The transformation of tarompa datuak design is imperative in the context of sociocultural change, since it is part of the preservation of cultural products and the development of the optimal potential of tarompa datuak can provide prosperity for the supporting community. Therefore, it is necessary to conduct this research with the aim to develop the design and ability of tarompa datuak crafters and improve their business managerial system, so that the potential of tarompa datuak handicraft can be optimized and become handicraft product that can compete amid global cultural arena. The method used in this research refers to qualitative research methodology, namely participative observation method, that is active observation.To make tarompa datuak design, then do some stages of research, that is: survey to center of handicraft tarompa datuak; exploration; analysis and synthesis; design with consideration of performance factor, function factor, marketing factor and consumer interest; then transformed into prototype tarompa datuak. For the empowerment of crafters held entrepreneurship training based on technology.
\end{abstract}

Key words: Transformation, Tarompa Datuak, Design Development, Sociocultural, Entrepreneurship.

\section{PENDAHULUAN}

Kerajinan tarompa datuak (sendal datuk) adalah bagian dari Usaha Mikro Kecil dan Menengah (UMKM) tradisional yang sampai saat ini masih ada di Sumatera Barat. Namun kalau diperhatikanpertumbuhan dan perkembangan kerajinan tarompa datuak, ibarat pituah (petuah) orang Minang, karakok di ateh batu, iduik sagan mati ndak namuah " (tanaman sirih yang tumbuh di atas batu besar, hidup segan matipun tidak mau), artinya perkembangan usahanya lambat dan atau hampir tidak jalan, tetapi masih bertahan. Di sisi lain, UMKM merupakan motor penggerak pembangunan Indonesia yang menyentuh semua lini (KADIN, 2009: 43). Kerajinan tarompa datuak, merupakan usaha kecil yang perlu dilindungi, diberdayakan, dan diberikan peluang usaha agar mampu dan sejajar dengan pelaku ekonomi lainnya, sehingga peran sertanya dalam pembangunan secara optimal. Untuk itu perlu terbangun kemitraan yang strategis dengan pihak-pihak terkait, seperti dengan usaha menengah dan usaha besar termasuk didalamnya Perguruan Tinggi dengan memperhatikan prinsip saling memerlukan, saling memperkuat dan saling menguntungkan (Keputusan Presiden Republik Indonesia Nomor 127 Tahun 2001 Tentang Bidang/ Jenis Usaha yang Dicadangkan Untuk Usaha Kecil 
dan Bidang/Jenis Usaha Yang Terbuka Untuk Usaha Menengah Atau Besar dengan Syarat Kemitraan, 2001).

Tarompa datuak merupakan bagian dari pakaian kebesaran Datuak (Datuk) yang dipakai Datuak saat upacara adat di Minangkabau. Tarompa datuak punya nilai etika dan estetika yang melekat dengan Pemangku Adat/Pangulu (Penghulu) yang dalam keseharian dipanggil dengan Datuk di Minangkabau. Sebagai seorang Pangulu, dalam berpakaian Datuak tentu punya pakaian kebesaran tersendiri. Pakaian itu merupakan cerminan dari prilaku yang menjadi kepribadiannya yang dituntut oleh adat. Pakaian Datuak itu terdiri dari: saluak (destar), baju gadang (besar), sarawa galembong (celana lapang), cawek (ikat pinggang), sampiang (kain yang disarungkan di pinggang), sandang/salempang (kain sarung yang diselempangkan ke bahu), karih (keris) dan tungkek (tongkat), dan tarompa (sendal). (Manggis, Karim, \& Saus Sutan Bagindo, 1976 15-22; Mutia, Munir, \& Alwi, 1996: 19-61).

Kerajinan tarompa datuak adalah salah satu bentuk kriya yang sudah lama berkembang di Sumatera Barat, pada zaman penjajahan Belanda juga sudah ada, sesuai dengan penjelasan Datuak Imuih (82thn) bahwa orang tua beliau yang bernama Datuak Putiah sudah membuat kerajinan ini sejak zaman Belanda (Amrizal, 2014: 341-342). Namun secara pasti kapan munculnya kerajinan ini belum ada data yang menjelaskan, akan tetapi keberadaanya dapat dilihat sebagai bagian dari keterampilan lokal masyarakat Minangkabau.

Pada tahun 1960-an di Padangpanjang, kerajinan ini sudah mencapai puncak kesempurnaan bentuknya dan tarompa datuak tidak hanya dipakai oleh Datuak tetapi dipakai oleh orang-orang kaya diwaktu itu. Anwar Datuak Rajo Pangulu (63 thn) menjelaskan bahwa tarompa datuak awalnya termasuk barang mewah, dan hanya dipakai oleh orang-orang kaya. Datuak termasuk orang kaya di kaumnya, sehingga dia juga memakai tarompa tersebut (Amrizal \& Yuliarni, 2016: 2). Hal ini juga sejalan dengan penjelasan Manggis (Manggis et al., 1976: 3) bahwa syarat menjadi datuak harus kaya, agar setelah menjadi datuak tidak menyusahkan anak kemenakannya dalam memenuhi kebutuhan hidupnya sehari-hari. Untuk membedakan tarompa yang dipakai datuak dengan tarompa yang dipakai orang kaya atau masyarakat biasa, Datuk Rajo Pangulu menjelaskan bahwa tarompa datuak diberi ragam hias atau kain songket pada permukaan (mukaan/upper) sedangkan tarompa yang dipakai orang kaya bentuk bagian permukaannya polos.

Perkembangan selanjutnya tarompa datuak tidak hanya dipakai oleh Datuak, tetapi berkembang sebagai salah satu bentuk karyakriya desain (cenderamata) yang sangat menarik dari Sumatera Barat. Kalau kita berkunjung ke Pasar Wisata Bukittinggi, cenderamata yang paling banyak ditemui adalah tarompa datuak, karena tarompa datuak dapat dimanfaatkan langsung oleh wisatawan dan selain itu tarompa datuak juga sudah dibuat sesuai dengan kebutuhan segmen pasar. Berdasarkan hal itu, sesuai dengan perjalanan waktu, bentuk tarompa datuak berkembang dalam berbagai variasi bentuk, ukuran, bahan dan teknik. Setiap perajin tarompa datuak, berdasarkan dimensi ruang dan waktu memiliki kreasi produk tersendiri yang berbeda di setiap perajinya.

Tarompa datuak, berdasarkan dimensi ruang dan waktu berkembang menjadi produk untuk industri pariwisata. Namun di sisi lain dapat dilihat bahwa pada dasarnya transformasi tarompa datuak ini tidak sejalan dengan pertambahan perajinnya, perajin tarompa datuak dilihat dalam perjalanan waktu terus berkurang jumlahnya. Hal itu menggambarkan sesuatu kenyataan yang bertolak belakang, di satu sisi sudah ada usaha pengembangan desain dan di sisi lain tidak signifikan dengan pertumbuhan dan kesejahteraan perajinnya.

Sebagai salah satu bentuk usaha di bidang kriya yang sudah lama berkembang, seharusnya usaha kerajinan tarompa datuak semakin pesat perkembangannya, namun kenyataannya usaha tarompa datuak saat ini sudah tergerus oleh waktu. Pada saat ini jumlah perajinnya semakin berkurang dan tidak ada regenerasinya. Para perajin pada umumnya sudah berumur di atas 50 tahunan dan generasi barunya boleh dikatakan tidak ada. Anak muda/generasi muda lebih memilih cara berwirausaha yang instan (cepat dapat uang/pagi bekerja sorenya langsung memperoleh uang), sulit diajak untuk berusaha di bidang kerajinan tarompa datuak ini, karena prosesnya lama dan lambat menghasilkan uang. Di Bukittiggi dan sekitarnya, perajin yang ada secara umum beralih usaha ke produk-produk tarompa yang laku di pasar (Muzakir, Wawancara 5 Mei 2017). Penyebab terjadinya hal itu, karena kurang lancar dan bagusnya pemasaran tarompa datuak, produk tarompa datuak kalah dalam persaingan dengan produk tarompa lain yang desain produknya lebih variatif, proses pembuatannya mempergunakan teknologi modern dan harganya lebih murah, dengan demikian di sisi ekonomi usaha kerajinan tarompa datuak tidak dapat mencukupi biaya kebutuhan hidup keluarga para perajinnya. Selain itu menurut Datuak Arlen bahan baku tarompa datuak terutama kulit samak nabati sulit mendapatkannya (Wawancara, 25 Juli 2015). Tetapi di sisi lain kalau kita cermati dan kita pakai atau gunakan sendiri tarompa datuak tersebut setiap hari, ternyata belum nyaman rasanya menggunakan tarompa datuak, karena masih terasa berat, keras atau tidak empuk, hak terlalu tinggi dan pada paku sol terlalu kelihatan sehinggga kurang elegan. (Amrizal \& Yuliarni, 2016: 10).

Sehubungan dengan uraian di atas sebagai produk kriya fungsional atau lebih tepatnya disebut dengan "kriya desain", yaitu benda atau produk untuk kepentingan ekonomi komersial (MA, 2016: 11), maka produk tarompa datuak perlu dikaji secara komprehensif untuk pengembangan desainnya agar keberadaannya 
tetap lestari sertaperajinnya tetap termotivasi untuk selalu aktif berproduksi. Sesuai dengan hal tersebut, maka penelitian yang dilakukan diarahkan pada pokok permasalahan: pertama, masalah bagaimana mengembangkan desain tarompa datuak agar dapat mengikuti selera zamannya,dan kedua bagaimana memberdayakan perajin tarompa datuak, agar perajin dan usaha kerajinannya tumbuh danberkembang dengan baik, sehingga perajinnya sejahtera serta usaha yang sudah mentradisi tersebut tetap lestari.Sukoco \& Muhyi, (2015: 158), mangatakan bahwa potensi usaha yang prospektif akan terus berkembang apabila para pengusaha termasuk perajin yang bergerak di bidang usaha tersebut mampu menumbuhkan usahanya dari waktu ke waktu secara berkelanjutan.

Pengembangan desain merupakan suatu upaya peningkatan kualitas produk daya saing produk tarompa datuakagar punya daya saing yang lebih baik di pasar yang lebih luas. Upaya peningkatan kualitas produk harus dibarengi dengan peningkatan kemampuan sumber daya manusianya (SDM), terutama dalam penguasaan teknologi, karena perkembangan teknologi selalu diikuti oleh peningkatan keinginan masyarakat(Rofiqah Wahdah \& Amalia, 2016: 94). Rufaidah \& Sutisna, (2015: 63)juga menjelaskan bahwa SDM yang bergerak pada UMKM dituntut memiliki kompetensi yang perlu dikembangkan setiap saat, sesuai dengan perkembangan selera pasar.

Untukmemberdayakan perajin agar tetap berproduksi dan tidak terputus generasinya, perlu dilakukan pelatihan untuk menumbuhkan jiwa berwirausahanya (Rofiqah Wahdah \& Amalia, 2016: 97). Pemberdayaan perajin ini, peneliti merujuk kepada faktor-faktor yang mempengaruhi keberhasilan pemberdayaan masyarakat miskin yang dikemukakan oleh Daraba, (2015: 167), yaitu: komunikasi, sumberdaya, disposisi, dan struktur birokrasi. Komunikasi antara peneliti atau pembimbing atau pendamping dengan perajin arus lancar, jelas dan konsisten. Memaksimalkan sumberdaya yang ada dengan disposisi yang terstruktur jelas dan profesional.

\section{METODE}

Untuk memudahkan proses penelitian, maka ditetapkan sebuah metode penelitian yang dapat menuntun dalam memecahkan permasalahan yang dikemukakan dengan cara ilmiah. Metode penelitian yang digunakan di sini adalah metode participation observation yang disebut juga denganobservasi aktif(Soedarsono, 2001: 149).Metode ini diharapkan dapat memandu peneliti mengikuti langkah-langkah sesuai prosedur penelitian.

Perwujudan desain tarompa datuak nantinya akan menggunakan alat dan bahan yang mengacu pada bahan dan alat yang digunakan dalam industri sendal dan persepatuan yang berkembang saat ini. Alat dan bahan itu sebagaimana yang di uraikan dalam buku Abdullatief \& Iswari, (2002: 7-10) terdiri dari: alat pres, plong pembuat nama, kayu kasbuk/solas, mesin gerinda, jarum, pengaris, gunting, mesin jahit, talenan, palu, open dan cutter. Sedangkan bahannya terdiri dari: lem, karet bergelombang/sol, karet simplex/karet keras, karet ati/penganjal dasar, kulit tersamak, karton duplek, tripleks, magic tape/perekat, gesper, slang kecil dan vuring/kain pelapis.

Pada saat akan mendesain tarompa datuak, pendekatan terhadap kebutuhan pasar, serta tujuan penelitiandijadikan acuan untuk menentukan konsep awal dari desain ini. Pengembangan desain tarompa datuakdilakukan pada bagian tampilan bentuk tali sendal, lapisan cetak, hak dan solnya agar semakin menarik untuk dilihat serta mampu menampilkan sebuah image baru dari tarompa datuak. Kemudian pengembangan tarompa datuak dilakukan melalui pengembangan bahan baku, bentuk, accessories serta kenyamanan dalam pemakaian. Adanya pengembangan yang melahirkan image baru tersebut maka diharapkan selera pasar terhadap tarompa datuak meningkat, tarompa datuakpunya nilai tawar yang baik ditengah-tangah masyarakat dan menjadi kerajinan yang punya daya saing ditengah percaturan budaya global.

Untuk itu dalam mendesain tarompa datuak sebagai suatu aktivitas dan karya budaya yang memiliki makna bagi perkembangan peradaban masyarakat Minang perlu diadopsi konsep estetika Jepang yang dijelaskan oleh Kenji Ekuan (Sachari, 1986:18-34). Ekuan menyatakan bahwa dalam mendesain ada dikenal dengan konsep "estetika kesederhanaan" yaitu mempertemukan elemenelemen yang kompleks menjadi satu kesatuan untuk melahirkan bentuk-bentuk yang sederhana. Pada estetika kesederhanaan dimana kompleksitas (keruwetan) tertanam dalam simplisitas (kesederhanaan), sederhana tapi bernilai, berkualitas, mempesonakan dan mencapai kemewahan.

\section{HASIL DAN PEMBAHASAN}

\section{Transformasi Desain Tarompa Datuak, Ditinjau dari Aspek Sosiokultural}

Transformasi menurut Putra (2006: 61) menunjuk pada berubahnya sesuatu tetapi seolah-olah tanpa melalui sebuah proses Transformasi diterjemahkan sebagai alih-rupa, perubahan hanya terjadi pada permukaannya saja atau hanya kulit luarnya saja, pada tataran bagian dalam tidak terjadi perubahan. Hal ini artinya identitas ataupun karakter dari produk yang berakar dari budaya lokal itu masih ada dan melekat dengan utuh. Adapun kunci transformasi menurut Zulaikha (2008: 1) terletak pada peningkatan kualitas SDM perajin, setelah itu introspeksi terhadap keunikan produk yang digeluti sebagai modal pengembangan desain, dan pengaturan manejerial. (Amrizal, 2010: 17-18).

Tarompa datuak menurut Datuk Imuih (Amrizal \& Yuliarni, 2016: 4), dalam hal bentuknya sangat sesuai dengan pakaian kebesaran Datuak yang lainnya dan 
serasi. Artinya bentuk tarompa dengan pakai hak tinggi lebih kurang $3 \mathrm{~cm}$, talinya 3 tancapan (1 di depan dan 2 di belakang) dan dibuat dengan kulit asli, sehingga menjadikan tarompa tersebut sangat serasi dan sangat cocok dipakai oleh Datuak. Tarompa tersebut serasi bentuknya dengan pakaian kebesaran Datuak yang lainnya, yaitu: destar, baju hitam besar lengan panjang, celana hitam besar kaki, kain sandang, kain samping, keris, tongkat, dan asesoris lainnya yang dipakai saat upacara adat, hal itu jelas menambah wibawa seorang Datuak di hadapan kaumnya/anak kemenakannya. Seandainya Datuak pakai sepatu, justru sangat tidak serasi dengan pakaian kebesaran Datuak yang lainnya, bahkan akan kelihatan tidak pantas/janggal. Celana hitam besar kaki yang terpasang di atas mata kaki (isbal) sangat serasi disatukan dengan alas kaki berupa tarompa datuak dari pada dengan memakai sepatu, Datuak akan tampil lebih berwibawa dan fleksibel dalam bergerak pada setiap upacara adat.

Untuk proses pembuatan tarompa datuak pada awalnya sangat sederhana, yaitu dengan bahan kulit samak $u b a(u b a=$ bahan penyamak kulit dan pewarna kulit dari kulit kayu uba/sejenis kayu akasia) atau samak semi kroom, tenun songket, kertas pola, paku sepatu, lem sintetis, benang nylon, vuring, tamsin (besi pingang), gesper dan karet ban (karet ban mobil yang sudah seset). Kulit yang digunakan ada dua jenis, yaitu kulit sapi untuk sol dan kulit kambing untuk tali dan mukaan sendal (bagian muka/depan sendal). Untuk alat yang digunakan juga dengan menggunakan peralatan yang sederhana, seperti pisau seset, palu besi, mesin jahit hitam (mesin jahit tua yang warnanya hitam), pensil, jarum, kayu gosokan, kertas karton/kertas pola, lilin, dan kayu gelondongan setinggi $50 \mathrm{~cm}$ dengan diameter 30-40 cm. Sedangkan untuk teknik yang digunakan adalah: teknik pola, gosok/glazing, potong, kempa, seset manual, cap/ stempel, jahit, lem dan paku. (Amrizal \& Yuliarni, 2016: 25-42).

Proses pembuatan tarompa datuak pada awalnya menggunakan teknik yang juga sangat sederhana, yaitu terlebih dahulu membuat dan menetapkan pola dasar, tanpa melalui sketsa dan desain. Pola pertama, pola untuk upper (atasan/tali), terdiri dari pola tali jepit dan mukaan. Kedua pola untuk bottom (bawahan/sol), yang terdiri dari sol dan hak. Untuk tahap berikutnya sebelum dilakukan pemindahan pola kekulit kulit digosok terlebeh dahulu dengan kayu gosokan (glazing) agar berkilat, kemudian dilanjutkan kepemolaan pada kulit dan dilanjutkan dengan pepotogan kulit sesuai dengan pola. Setelah itu dilakukan proses perakitan dengan teknik seset, lem, jahit dan paku. Untuk finishing pada bagian sisi sol agar mengkilat, sisi-sisi sol di olesi dengan lilin, kemudian digosok dengan kayu likut.(Amrizal \& Yuliarni, 2016: 48-59).

Penetapan ukuran/penomoran dalam pembuatan tarompadatuakberpedomanpadaukurankakisipembuat/ perajin atau pemesan, artinya tanpa menggunakan acuan/cetakan atau solas. Perajin menetapkan besar kecil ukuran tarompa datuak berdasarkan perbandingan ukuran kaki perajin. Untuk membuat ukuran yang besar, maka ukurannya dilebihkan sedikit dari ukuran kaki perajin dan untuk membuat ukuran yang kecil, perajin membuatnya dengan mengurangi ukuranya sedikit dari ukuran kaki perajinnya. Kalau ada ukuran yang lain, harus menyesuaikan dengan ukuran yang ada atau dipesan untuk di ukur langsung oleh perajinnya. (Herman, wawancara, 30 Juli 2015).

Pada bagian upper (atasan), yang pertama dipersiapkan yaitu mukaan (tali sendal), kulit dipotong sesuai ukuran pola untuk mukaan. Mukaan bagian tengahnya diisi dengan tali sabut kelapa atau tali ijuk dan atau tali plastik ukuran $0.3 \mathrm{~mm}$ agar berbentuk bulat, kemudian di lem dan dijahit. Mukaan dibuat dua lapis, lapisan luar digunakan kulit samak nabati atau tenun songket Pandai Sikek dan pada bagian lapis kedua juga digunakan kulit samak nabati atau diberi vuring, kemudian dilem dan dijahit. Mukaan bagian luar yang menggunakan kulit samak nabati, biasanya kulit tersebut dicap/stempel, ditatah, di sulam, dan atau diberi manik-manik. Untuk bagian bottom (bawahan), sol dan hak/tumit digunakan kulit sol samak nabati atau samak $u b a$, perakitan setiap bagian sol dan tumit/hak menggunakan paku atau lem sintetis. Sol pada dasarnya terdiri dari: lemek (sol lapis atas atau pada sepatu disebut insole sol dalam atau tapak bagian atas), sol tengah, sol luar dan setengah sol (berbahan/karet sol), dan hak juga terdiri dari lapisan tengah (lapisan hak) dan lapisan luar (cup/tutup hak). Pada awal berkembangnya kerajinan tarompa datuak, untuk membuat solnya hanya menggunakan kulit samak uba dan perakitannya tidak menggunakan lem, tetapi hanya menggunakan paku saja, hal ini disebabkan oleh kulit samak $u b a$ kalau dilem tidak tahan lama, karena kandungan airnya masih tinggi. (Amrizal \& Yuliarni, 2016: 51-54).

Berdasarkan ruang dan waktu, bahan, alat dan teknik yang digunakan perajin juga mengikuti perkembangan zamannya, yaitu mengikuti perkembangan alat untuk industri alas kaki lainnya. Bahan yang digunakan selain bahan yang disebutkan di atas, pada saat ini sudah menggunakan bahan karet mika, karet ati/karet sol tenggah, dan shoepolish untuk finishing. Peralatan yang digunakan sudah menggunakan mesin ampelas, mesin jahit phostbad, plong tunggal, plong ganda, cutter, pemasang keling, landasan kaki tiga, pahat hias dan pahat kerawang. Sedangkan teknik yang baru digunakan adalah teknik press, gerinda, seset mesin, kerawang, anyam dan sulam. Bentuk dan fungsi tarompa datuak juga bertransformasi mengikuti zamannya. Dilihat dari sisi bentuk, pada bagian atasan dan sol tarompa datuak berkembang sesuai dengan selera pasar dan konsumennya. Untuk fungsi juga demikian, tarompa datuak yang digunakan untuk sebagai bagian dari pakaian 
kebesaran Datuak berkembang menjadi produk yang dapat dipakai oleh semua kalangan dan produk untuk industri pariwisata. (Amrizal \& Yuliarni, 2016: 13, 62)

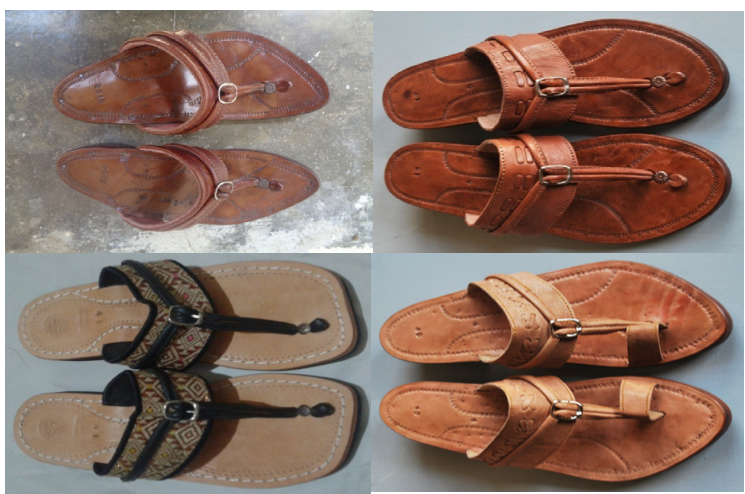

Gambar 1. Bentuk Transformasi Desain Bagian Atasan Tarompa Datuak dalam Dimensi Ruang dan Waktu (Foto: Amrizal, 2017)

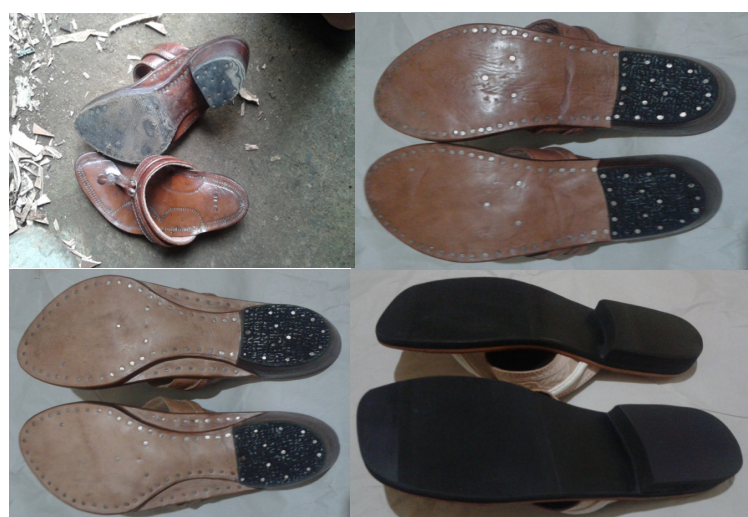

Gambar 2. Beberapa Bentuk Transformasi Bagian Sol Tarompa Datuak dalam Dimensi Ruang dan Waktu (Foto: Amrizal, 2017)

\section{Pengembangan Desain Tarompa Datuak}

Pengembangan pada dasarnya merupakan suatu usaha untuk meningkatkan kemampuan konseptual, teoritis, teknis dan moral individu sesuai dengan kebutuhan pekerjaan, dan jabatan melalui pendidikan dan pelatihan (Alyas \& Rakib, 2017: 116). Widagdo (2005: 8a), menjelaskan bahwa istilah desain sangat luas pengertiannya, jadi yang dimaksud dalam tulisan ini adalah wujud perancangan yang menghasilkan wujud benda untuk memenuhi kebutuhan hidup manusia dalam lingkup seni rupa dan desain yang berorientasi ekonomi pasar serta produksi masa. Sementara itu dalam hal pengembangan desain yang dimaksudkan dalam penelitian ini adalah usaha untuk melakukan inovasi terhadap produk yang sudah adasehingga produk tersebut lebih variatif sesuai dengan kebutuhan dan keinginan konsumen atau selera pasar melalui langkah-langkah penciptaan karya/produksehingga memiliki makna bagi perkembangan peradaban masyarakat.

Desain sebuah produkmenjadi faktor yang penting dalam pengembangan produk.Bagi pengusaha desain produk yang baik adalah yang mudah diproduksi dan didistribusikan, sedangkan bagi konsumen desain produk yang baik adalah yang menyenangkan mata dan mudah dibuka, dipasang, digunakan, diperbaiki dan dibuang (Mahmud \& Eko Agus Alfianto, 2014: 30).Secara umum faktor penentu keberhasilan produk terletak pada konsumen, untuk itu desain yang dibuat harus disesuaikan dengan kebutuhan dan keinginan konsumenHaryono \& Bariyah, (2014: 71). Selain itu dalam mendesain sendal, nilai kenyamanan si pemakai harus menjadi prioritas utama dan dalam menentukan ukuran harus mengikuti standar ukuran yang baku (Abdullatief \& Iswari, 2002: 3).Untuk itu keinginan pengusaha (produsen) dengan keinginan konsumen harus sinkron dalam sebuah desain.

Langkah awal dalam pembuatan desain yaitu: memikirkan model desain yang layak untuk dikembangkan (pencarian ide kreatif); mewujudkan dalam berbagai macam model produk (sketsa alternatif); kemudian dilanjutkan dengan menentukan ukuran dan memilih model yang nyaman, serasi dan menarik (membuat gambar kerja); langkah selanjutnya melakukan validasi kepada ahlinya (kriyawan atau perajin yang empu), agar desain yang dibuat maksimal sebelum dibuat menjadi produk yang siap untuk dipasarkan (Mulya \& Mutmainah, 2017: 378). Pendapat itu sejalan dengan yang dipaparkan oleh SP.Gustami (2007: 329), yaitu terdapat tiga tahap penciptaan produk kriya: (1) eksplorasi (problem solving, acuan visual); (2) perancangan (menvisualkan ide dalam bentuk sketsa yang berlanjut sampai gambar kerja, prototipe); dan (3) perwujudan (buat produk sesuai prototipe, evaluasi/uji kelayakan).

Saidani, Rachman \& Rizan, (2013:205) menjelaskan bahwa desain menawarkan tiga hal, yaitu: fungsi, estetika dan daya tarik. Seterusnya Mahmud \& Alfianto, (2014: 30), juga menegaskan bahwa masalah desain dari sebuah produk sangat perlu mendapatkan perhatian serius dari team pengembangan produk atau pihak produsen, karena untuk dapat bersaing disetiap segmen pasar, suatu produk harus mampu memenuhi kebutuhan dan keinginan konsumennya, baik dari aspek fungsi, estetika ataupun daya tarik yang dimiliki produk tersebut. Untuk itu, maka pengembangan desain tarompa datuak dimulai dari tahap mentransformasikan tarompa datuak menjadiproduk yang bukan sekedar menjadi pakaian kebesaran para Datuk saja, melainkan sudah menjadi produk untuk semua segmen pasar dan termasuk untuk industri pariwisata. Yoety (2008: 27) mengatakan industri pariwisata turut melestarikan dan mendorong kreatifitas para perajin serta sekaligus memperluas pasar ke dunia internasional.

Pembuatan desain tarompa datuak diawali dari melakukan eksplorasi seluruh produk tarompa datuak yang ada di sentra-sentra kerajinan tarompa datuak yang ada di Padang Panjang dan Di Bukittinggi sekitarnya serta ditambah dengan browsing aneka model sendal di internet untuk mendapatkan ide kreatif. Produk yang ada sentra-sentra atau di toko tersebut di foto, sebagian dibeli untuk contoh real dalam pengembangan desain. 
Perkembangan model sendal yang di pasar-pasar juga difoto dan yang di-browsing di internet di print, sehingga dapat jadi inspirasi dalam mendapatkan model yang sesuai dengan tren.

Berdasarkan penelitian yang telah dilakukandi Padang Panjang dan Bukittinggi sekitarnya ditemukan beberapamodel dan ukuran Tarompa datuak yang kemudian digunakan sebagai inspirasi untuk pengembangan desain atau pembuatan desain baru dalam penelitian ini. Tarompa datuak itu ada yang model biasa/ model standar, model klasik dan model petak. Tali atau mukaan ada yang polos dan ada yang diberi hiasan dengan di cap, di sulam, di anyam dan di beri tenun songket. Sedangkan sol ada yang berbentuk standar dan ada yang berbentuk klasik serta ketebalan sol antara 1 $1.5 \mathrm{Cm}$ dan hak $3-3.5 \mathrm{Cm}$.

Untuk bahan yang digunakan sudah beraneka ragam, ada yang menggunakan kulit samak nabati kombinasi songket Panadai Sikek untuk tarompa datuak yang asli dan kulit samak chroom, dan ada yang memakai kulit samak nabati kombinasi oscar, vinil dan karet ati untuk tarompa datuak yang sudah bertranformasi. Produk yang asli sol dan hak semuanya menggunakan bahan kulit samak nabati dan untuk membuat ketebalannya menggunakan paku, sedangkan tarompa datuak yang sudah bertranformasi solnya menggunakan karet ati dan untuk menambah ketebalannya menggunakan lem sintetis. Dihat dari sisi beratnya produk, tarompa datuak yang asli dengan sudah bertranformasi juga sangat jauh berbeda, yang asli beratnya lebih kurang 700 gram sampai dengan 800 gram, sedangkan yang sudah bertranformasi beratnya hanya 450 gram sampai dengan 500 gram.

Setelaheksplorasidianggapcukup, makadilakukan perancangan yang diawali dari membuat sketsa-sketsa alternatif, kemudian sketsa dipilih yang terbaik dan dipindahkan menjadi gambar kerja. Pada gambar kerja sudah tergambar ukuran yang jelas dan pecah pola sesuai elemen-elemen tarompa yang dirancang. Gambar kerja tersebut sebelum diwujudkan menjadi sebuah prototipe, terlebih dahulu di konsultasikan atau divalidasi keperajin di Padang Panjang dan Bukittinggi, dan setelah itu diwujudkan menjadi sebuah prototipe. Prototipe ini setelah dievaluasi/uji kelayakan, maka desain baru tarompa datuak siap untuk diproduksi.

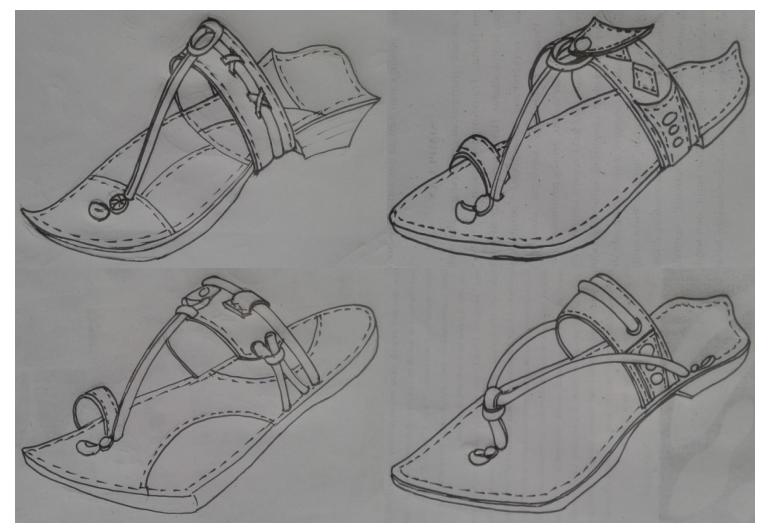

Gambar 3. Bentuk Pengembangan Desain Tarompa Datuak (Desain: Amrizal, 2017)

\section{Pemberdayaan Perajin}

Produk alas kaki merupakan salah satu produk yang dibutuhkan konsumen untuk semua kalangan. Dewasa ini, alas kaki tidak sekedar untuk melindungi kaki agar tidak kotor atau cidera, tetapi sudah menjadi bagian dari gaya hidup. Tarompa datuak bukan sekedar menjadi pakaian kebesaran para Datuk, melainkan sudah menjadi produk untuk semua segmen pasar. Jadi dengan demikian sangat diperlukan desain baru dan pemberdayaan perajin agar usaha kerajinan tarompa datuak tumbuh dan berkembang sesuai zamannya.

Untuk meningkatkan daya saing usaha kerajinan tarompa datuak di tengah percaturan budaya global, perlu di adopsi strategi yang dikemukakan (Nurzamzami \& Siregar, 2014:29), yaitu: mengadakan pelatihan motivasi, pelatihan kewirausahaan, peningkatan mutu dan kinerja perajin; memperluas pangsa pasar dengan memanfaatkan media semua promosi; meningkatkan kualitas dan karakter produk; serta menggunakan teknologi untuk menghasilkan produk yang bermutu, inovatif dan promosi yang efektif. Harefa \& Siadari, (2008: 16-24) mengatakan bahwa orang yang berjiwa wirausaha/berbakat wirausaha atau sedikit memiliki bakat atau tidak merasa memiliki bakat wirausaha perlu di motivasi melalui pembelajaran yang berkelanjutan, lingkungan yang kondusif, terbuka, mengakui keungulan orang lain dan belajar dari kesuksesan orang lain.

Wirausaha secara leksikal sama dengan wiraswasta yaitu orang yang pandai atau berbakat mengenali produk baru, menentukan cara produksi baru, menyusun operasi untuk pengadaan produk baru, memasarkannya, serta mengatur permodalan operasinya (http://badanbahasa. kemdikbud.go.id/kbbi/, diakses 28 Agustus 2017). Wirausaha saat ini sangat terkenal disebut dengan entrepreneur yang artinya pengusaha, dan usahawan. Ciputra, (2009: 61-62) mengatakan bahwa seorang entrepreneur pasti seorang pengusaha tetapi tidak semua pengusaha adalah entrepreneur, seorang entrepreneur adalah orang yang mampu mengubah kotoran dan rongsokan menjadi emas. Jadi pengembangan kemampuan entrepreneur ini dimaksudkan sebagai suatu usaha untuk meningkatkan kemampuan konseptual, teoritis, teknis dan moral perajin untuk dapat memiliki jiwa kewirausahaan, agar usaha kerajinan tarompa datuak tetap tumbuh dan berkembang dengan baik, sehingga kehidupan perajinnya sejahtera dan usaha yang sudah mentradisi di Ranah Minang tetap lestari.

Perancangan desain ada "estetika kesederhanaan", dalam kewirausahaan ada "kekuatan kesederhanaan" (the power of simplicity). Seorang wirausahawan bisa kreatif, berani, bisa bertindak dan berpikir cepat, menjadi ahli dan menguasai keadaan, karena mereka menikmati kekuatan dari kesederhanaan, mereka berfikir tidak ruwet, mereka mengerjakan yang mereka kenali dan segala hal yang sulit mereka buat menjadi sederhana. Thomas A. Edison mengungkapkan bahwa "karena berpakaian 
yang kompleks dan menggunakan cara berfikir seperti orang bekerja, banyak peluang yang hilang”. Banyak orang berpikir dirinya dipandang hebat kalau mereka bisa membuat yang mudah menjadi sulit, dalam kewirausahaan sebaliknya harus dilakukan, kalau anda membuatnya menjadi kompleks tidak akan bertahan. (Kasali, 2010: 55-57).

Setelah diadakan pelatihan motivasi kewirausahaan, peningkatan mutu dan kinerja perajin, maka untuk mengukur keberhasilannya dapat digunakan konsep enterpreneurial marketing yang dikemukakan oleh Septiani, Sarma, \& Limbong, (2013: 92,108). Enterpreneurial marketing merupakan sebuah pendekatan yang berorientasi pada inovasi dan penerapan strategi bottom-up (penyesuaian produk dengan permintaan konsumen). Perbaikan dalam hal pemberdayaan perajin tarompa datuak dapat dikatakan berhasil apabila terjadi peningkatan kemampuan daya saing yang tercermin dari indikator: peningkatan jumlah pelanggan, peningkatan cakupan wilayah pemasaran, peningkatan jumlah penjualan produk kepada pelanggan baru.

\section{SIMPULAN}

Tarompa datuak merupakan tarompa pakaian kebesaran Datuk di Ranah Minang Sumatera Barat. Transformasi desain tarompa datuak tidak lepas dari konteks perubahan sosiokultural. Berdasarkan dimensi ruang dan waktu kerajinan tarompa datuak berkembang mengikuti perubahan prilaku masyarakat pendukungnya. Proses pembuatan tarompa datuak pada dasarnya sangat sederhana, seiring perjalanan waktu, proses pembuatan tarompa datuak mengikuti perkembangan proses produk alas kaki secara umum. Pembuatan desain tarompa datuak diawali dari melakukan eksplorasi seluruh produk tarompa datuak yang ada di sentra-sentra kerajinan tarompa datuak yang ada di Padang Panjang dan Di Bukittinggi sekitarnya serta ditambah dengan browsing aneka model sendal di internet untuk mendapatkan ide kreatif; kemudian dilakukan perancangan yang diawali dari membuat sketsa-sketsa alternatif, kemudian sketsa dipilih yang terbaik dan dipindahkan menjadi gambar kerja; dan terakhir diwujudkan menjadi sebuah prototipe. Prototipe ini setelah dievaluasi/uji kelayakan, maka desain baru tarompa datuak siap untuk diproduksi.

Untuk pemberdayaan perajin tarompa datuak diadakan pelatihan motivasi, pelatihan kewirausahaan, peningkatan mutu dan kinerja perajin; workshop memperluas pangsa pasar dengan memanfaatkan media semua promosi. Disamping itu juga diadakan workshop untuk meningkatkan kualitas dan karakter produk; serta pelatihan menggunakan teknologi untuk menghasilkan produk yang bermutu, inovatif dan promosi yang efektif.

\section{DAFTAR PUSTAKA}

Abdullatief \& Iswari, D. (2002). Membuat Sendal \& Sepatu Santai untuk Wirausaha. Jakarta: Puspa Swara. Jakarta: Puspa Swara.

Alyas \& Rakib, M. (2017). Strategi Pengembangan Usaha Mikro, Kecil dan Menengah dalam Penguatan Ekonomi Kerakyatan (Studi Kasus Pada Usaha Roti Maros di Kabupaten Maros). Sosiohumaniora, 19(2), 115-121.

Amrizal (2010). Transformasi Wayang Kulit Pedalangan ke Wayang Kulit Cenderamata di Pucung, Imogiri, Yogyakarta. Yogyakarta.

Amrizal (2014). Kerajinan Kulit Padangpanjang: Antara Peluang dan Tantangan. Jurnal Ranah Seni: Jurnal Seni Dan Desain, 7(2), 339-352.

Amrizal \& Yuliarni. (2016). Proses Produksi Kerajinan Tarompa Datuk. Padangpanjang: LPPMPP ISI Padangpanjang.

Ciputra (2009). Ciputra Quantum Leap: Entrepreneurship mengubah Masa Depan Bangsa dan Masa Depan Anda. Jakarta: Gramedia.

Daraba, D. (2015). Faktor-Faktor yang Mempengaruhi Keberhasilan Program Pemberdayaan Masyarakat Miskin di Kecamatan Polongbangkeng Utara Kabupaten Takalar Propinsi Sulawesi Selatan. Sosiohumaniora, 17(2), 168-169.

Harefa, A. \& Siadari, E.E. (2008). The Ciputra Way Praktik Terbaik Menjadi Entrepreneur Sejati. Jakarta: Gramedia.

Haryono, M. \& Bariyah, C. (2014). Perancangan Konsep Produk Alas Kaki dengan Menggunakan Integrasi Metode Kansei Engineering dan Model Kano. Jurnal Ilmiah Teknik Industri, 13 (1), 7182.

Herman. (n.d.). Pengusaha kerajinan tarompa datuak "Merapi Shoes" di Bukittinggi. Bukittinggi: Wawancara.

http://badanbahasa.kemdikbud.go.id/kbbi/.(n.d.). Kewirausahaan.

KADIN. (2009). Roadmap Pembangunan Ekonomi Indonesia 2009-2014. Jakarta: www.kadin. indonesia.or.id.

Kasali, R. (2010). Wirausaha Muda Mandiri: Ketika Anak Sekolah Berbisnis. Jakarta: Gramedia Pustaka Utama.

Keputusan Presiden Republik Indonesia Nomor 127 Tahun 2001 Tentang Bidang/Jenis Usaha yang Dicadangkan Untuk Usaha Kecil dan Bidang/ 
Jenis Usaha yang Terbuka Untuk Usaha Menengah atau Besar dengan Syarat Kemitraan (2001).

Mahmud, \& Alfianto, E.A. (2014). Pengaruh Desain Produk dan Layanan Purna Jual Terhadap Keputusan Konsumen Membeli Sepeda Motor Yamaha Merek New V-IXION FI (Full Injection) (Studi pada Konsumen Sepeda Motor Yamaha Merek New V-IXION FI (Full Injection) di Adiguna Sakti Motor Pandaan). Jurnal Sketsa Bisnis, 1, 1130-1132.

Manggis, M.R.D.R.P., Karim, A. \& Bagindo, S.S. (1976). Limpapeh: Adat Minangkabau (Jilid II:). Bukittinggi: Perc. Unit II Bkt.

Mulya, A.N. \& Mutmainah, S. (2017). Pengembangan Desain Produk Anyam Bambu di Desa Sukolilo Kecamatan Sukodadi Kabupaten Lamongan. Jurnal Seni Rupa, 5 (2), 375-384.

Mutia, R., Munir, D. \& Alwi, N. (1996). Pakaian Penghulu Minangkabau. Padang: Proyek Pembinaan Permuseuman Sumatera Barat.

Muzakir. (2017). Wawancara dengan Perajin Tarompa Datuak di Panta, 5 Mei 2017. Kabupaten Agam.

Nurzamzami, A. \& Siregar, E.H. (2014). Peningkatan Daya Saing UMKM Alas Kaki di Kecamatan Ciomas, Kabupaten Bogor dan Implikasinya terhadap Strategi Pemasaran. Jurnal Manajemen Dan Organisasi, V (1), 15-29.

Rofiqah Wahdah, \&Amalia, H.S. (2016). Pengembangan Daya Saing Produk pada Sentra Kerajinan Purun di Kabupaten Hulu Sungai Utara Kalimantan Selatan. Jurnal Spread, 6 (2), 89-99.
Rufaidah, P. \& Sutisna. (2015). Kapabilitas Dinamis UMKM Industri Kreatif Jawa Barat. Sosiohumaniora, 17 (1), 60-66.

Sachari, A. (1986). Seni Desain dan Teknologi: Antologi Kritik, Opini dan Filosofi. Bandung: Pustaka.

Saidani, B., Rachman, M.A. \& Rizan, M. (2013). Pengaruh Kualitas Produk dan Desain Produk Terhadap Keputusan Pembelian Sepatu Olahraga Futsal Adidas Di Wilayah Jakarta Timur. Jurnal Riset Manajemen Sains Indonesia. Jurnal Riset Manajemen Sains Indonesia (JRMSI), 4 (2), 201-217.

Septiani, S., Sarma, M. \& Limbong, W.H. (2013). Pengaruh Entrepreneurial Marketing dan Kebijakan Pemerintah terhadap Daya Saing Industri Alas Kaki di Bogor. Jurnal Manajemen Dan Organisasi, IV (2), 91-111.

Soedarsono, R.M. (2001). Metode Penelitian Seni Pertunjukan dan Seni Rupa. Bandung: Masyarakat Seni Pertunjukan Indonesia.

Gustami, SP. (2007). Butir-Butir Mutiara Estetika Timur: Ide Dasar Penciptaan Seni Kriya Indonesia. Yogyakarta: Prasista.

Sukoco, I. \& Muhyi, H. A. (2015). Ecopreneurship Dalam Menumbuhkan Usaha Berwawasan Lingkungan Pada Sentra Industri Penyamakan Kulit Sukaregang Kabupaten Garut. Sosiohumaniora, 17(2), 156-165.

Widagdo. (2005). Desain dan Kebudayaan. Bandung: ITB.

Yoety, O.A. (2008). Ekonomi Pariwisata: Introduksi, Informasi dan Implementasi. Jakarta: Kompas. 